\title{
Economic Analysis for Effects of Policies to Support Price of Products and Prices of Inputs for Meat in Iraq
}

\author{
Norsida Man ${ }^{1}$, Sarmad Ali Hussein ${ }^{1,2}$, Ismail Latif ${ }^{1} \&$ Nitty Hirawaty ${ }^{1}$ \\ ${ }^{1}$ Department of Agribusiness and Bioresource Economics (Agricultural Economics), Universiti Putra Malaysia, \\ UPM Serdang, Selangor, Malaysia \\ ${ }^{2}$ Al-Furat Al-Awsat Technical University mussaib Technical College, Iraq \\ Correspondence: Norsida Man, Department of Agriculture Technology, Faculty of Agriculture, Universiti Putra \\ Malaysia (UPM), 43400 Serdang, Selangor, Malaysia. E-mail: Norupi45@yahoo.com
}

Received: May 31, 2017

doi:10.5539/ass.v13n10p10
Accepted: July 17, $2017 \quad$ Online Published: September 28, 2017

URL: https://doi.org/10.5539/ass.v13n10p10

\begin{abstract}
This work aims to measure the cost of supporting both the product price support policy and also support input prices, then the comparison between the two policies for their preference between them. The problem of study that the state when implementing the two policies bear sums from the public treasury. Analysis based on the collection of data from the sample of study, a beef and fish meat contains time series on prices, production and consumption depends on the style of mathematics to get the results. The results arrived that the state gets revenue through support product price policy, but the returns were not in the producers have been negatively affected consumer prices up meat. On the other hand the state bore the costs by supporting input prices in order to be provided to producers. Therefore we prefer the input support policy for the economic and productivity. The study recommends that support the agricultural sector policy planning and rehabilitation support commodity price policy.
\end{abstract}

Keywords: support policy, product price, input price, Iraq

\section{Introduction}

Many countries resort to determine the prices of agricultural products, especially grain and meat. The reasons for this intervention is due to the nature of agricultural commodities and low elasticity of demand and supply them. Also to improve the incomes of agricultural producers and prevent monopoly and to develop and increase production. State intervention is through either remunerative price to the final output of goods in the sense support producer prices, as well as supporting consumer prices, especially meat, which is characterized by high price in local markets. In both cases, whether to support the resulting price of the product or the consumer, the State bears the costs of this policy and the burden of its treasury, since you are buying meat from local producers at prices supposed to be rewarding for them to continue in the production process, and sells it to consumers at a price commensurate with the level of their income (the price of the state) The price is supposed to be supported. Thus, the State bears the difference between the purchase and selling price of the product price when you ask selling price (the price of the state) of the purchase price (the local price of the product), we get the amount of the cost of support per unit of output and we can get on the amount of the cost of the support the college by multiplying the amount of consumption in the amount of the cost of support per unit of output. Also the State support input prices in order to provide producers and the state here also bear the costs of imported or locally produced and sold at a reasonable price for producers and the state bear the price differences. In this research will be analysing the results of the policies of the product price support and input subsidies for trade-offs between the two policies in economic terms costs.

\section{Problem of Study}

Many countries, including Iraq, follow two approaches to support agricultural products which support product prices policy and support input prices policy. Research problem in differing economists to identify any of the two policies who are competent economically and see from those best policies for producers and less cost to the state treasury. 


\section{Objective of Research}

The research aims to calculate the costs to support product prices and the cost of input support for the differentiation between the two policies.

\section{Methodologies}

The study based on the use of time series data includes state, global and market prices. Quantities of domestic production and consumption in addition to the surplus of producers and consumers. The research sample used for fish and beef. Analysis relies on the use of some simple mathematical operations on data in addition to the descriptive style and the comparison between the results in order to determine the favourite policy.

\section{Support Price of Product}

Support the price of the product policy is one of the direct means to support agricultural commodities and food, and the state depends on this policy in order to increase production and secure the food needs of the population (Zobaie, 1995). As a result of insufficient domestic production, the country covering consumer demand through imports, as the state used to support the resulting price to stimulate producers to increase production in order to increase the quantities produced and reduce import policy. If state want to support the price of the output of the product or the consumer, they bear the costs of its treasury, since you are buying the item from local producers at prices supposed to be rewarding for them to continue in the production process, and sells it to consumers at a price commensurate with the level of their income (the price of the state) and is supposed to be pricier supported. Thus, the State bears the difference between the purchase price and the selling price of the product in question and when you ask selling price (the price of the state) of the purchase price (consumer price) we get the amount of the cost of support per unit of output and we can get on the amount of the cost of the total support the by multiplying the amount of consumption in the amount of the cost of support per unit of the commodity(Bayaty, 2007). Then subtract the surplus of producers and consumers for the purpose of obtaining the cost of the state to support the product price

\section{Support Input Price}

One of the means of price policy used by the state is to support the policy of input and output prices, which contribute to stimulate commodity producers and encourage them to increase their output any increase domestic production is the most important goals of that policy. Production inputs include concentrates feed and veterinary medicines and sterilizers necessary for the production of meat, both beef and fish. State working on the import of these inputs and provide the product at a price supported. As in product support rate policy is also the state treasury bears the difference between the sale of these input prices to the producers and the real price of these inputs, which is nearly the world price (border price) and represent these price differences the cost of supporting the input output per unit of the commodity (Modha \& Kanaan, 2000). Operation hit this cost in the amount of production we can get the cost of the overall support for the production of any commodity inputs.

\section{Results and Discussion}

The results are analyzed to support the final product price of the commodity costs compared with support for input costs. It will be now analyze and calculate the results of those costs. So we divided this section into two sides support prices of goods and support for input prices

\subsection{Result for Support Price of Goods}

By analyzing the results for Beef is clear that support output rate results were negative with respect to the consumer and for all years of study. Because it was a single consumer unit output of beef is higher than the price of the gross domestic product price. So that means the state achieved revenues as a result of the price of the policy pursued by, as the recommended retail price was greater than the purchase price of the product. As it can show in Table 1. The amount of profits gained by the state characterized by fluctuating during the study period was the lowest return (53.76) thousand dinars in 1985, and the highest return for the state through policy support $(486,609)$ thousand dinars in 2012 , when the negligence of reference for negative amount of the money becomes returns to the State, rather than the cost of support. Therefore we conclude that the price policy pursued by the state in support of the product price of beef has made revenue for the state during the period of the study, as there was positive support for the price of the producers, while state support was negative and is a catalyst for the consumer.

Consequent price policy of the State to support the beef price of certain so-called cost of supplier support level is this cost calculated by subtracting changes in surplus producer and consumer calculated from the total of the state cost as a result of supporting output mentioned rate policy, in other words, the cost supplier is a those cost 
of the subsidy program after subtracting the producers and consumers the benefits and the measured changes in the surpluses of the producer and consumer, and that this cost (the cost of the supplier) is not benefiting producers and consumers but are paid by the state are considered administrative costs for the application of the subsidy program. Table 2 shows the cost of the supplier of the state during the period of study values. Note the table when we find that the State has achieved returns through policy interventions to support the price of beef in years (1995-2008) as well as 2013, we find that Rate this revenue has fluctuated between increases and decreases have reached a higher amount $(162,676.79)$ thousand dinars in 2013 and reached its lowest amount (75.80) thousand dinars in 2000.

Table 1. State Support Amounts for Beef for the period (1985-2013)

\begin{tabular}{cccccc}
\hline Years & $\begin{array}{c}\text { Purchasing } \\
\text { price(ID } \backslash \mathrm{Kg})\end{array}$ & $\begin{array}{c}\text { Consumer } \\
\text { price(ID } \backslash \mathrm{Kg})\end{array}$ & $\begin{array}{c}\text { Support } \\
(\mathrm{ID} \backslash \mathrm{Kg})^{*}\end{array}$ & $\begin{array}{c}\text { consumption } \\
(\text { (000tons) }\end{array}$ & $\begin{array}{c}\text { Total Support } \\
(\text { (000ID)* }\end{array}$ \\
\hline 1985 & 2.9 & 3.14 & -0.24 & 224 & -53.76 \\
1990 & 6.3 & 7.73 & -1.43 & 134.38 & -192.163 \\
1995 & 1196 & 1305 & -109 & 84.74 & -9236.66 \\
2000 & 2252 & 2350 & -98 & 70.3 & -6889.4 \\
2001 & 2835 & 2867 & -32 & 65.83 & -2106.56 \\
2002 & 2549.2 & 3122 & -572.8 & 130.54 & -74773.3 \\
2003 & 2545.3 & 4125 & -1579.7 & 132.4 & -209152 \\
2004 & 3046.7 & 4750 & -1703.3 & 132.3 & -225347 \\
2005 & 3646.9 & 5250 & -1603.1 & 134.35 & -215376 \\
2006 & 4365.3 & 6500 & -2134.7 & 136.59 & -291579 \\
2007 & 5225.3 & 7250 & -2024.7 & 139.16 & -281757 \\
2008 & 6254.7 & 7900 & -1645.3 & 150.46 & -247552 \\
2009 & 9100 & 10800 & -1700 & 254.9 & -433330 \\
2010 & 12559 & 13900 & -1341 & 330.7 & -443469 \\
2011 & 13485 & 14670 & -1185 & 330.1 & -391169 \\
2012 & 13931 & 15000 & -1069 & 455.2 & -486609 \\
2013 & 14126 & 15250 & -1124 & 157.11 & -176592 \\
\hline
\end{tabular}

Source: data prices and quantities are taken from the Ministry of Planning and the Ministry of Agriculture statistics

*Negative point to earn revenue of the state, while the positive represents the cost support price

State revenues will fluctuate on factors such as the volume of consumption and the price of a single-dependent as it's up these two variables increase state revenues and decreases the signal decreases. The rest of the years of study that is not previously listed have resulted in the state the cost of the resource as a result of price support for the beef product policy has reached the maximum amount it $(1,691,978.10)$ thousand dinars in 2010 , the lowest amount it has reached (17.13) thousand dinars in 1990. Why the fluctuation of the cost of the resource values to a number of factors, including the amount of consumption of the commodity as well as a surplus producer and consumer surplus as these variables affect the overall cost of support and then the cost of supplier arising from the item price support program.

Table 2. The Cost of Support the Price of Beef for the period (1985-2013) (000ID)

\begin{tabular}{ccccc}
\hline Years & The total Support & CS & PS & the cost of Support \\
\hline 1985 & -53.76 & -161.25 & 58.12 & 49.37 \\
1990 & -192.163 & -420.071 & 210.78 & 17.13 \\
1995 & -9236.66 & -3330.06 & 2622.45 & -8529.05 \\
2000 & -6889.4 & -48632.1 & 41818.45 & -75.80 \\
2001 & -2106.56 & -85087.4 & 73250.99 & 9729.89 \\
2002 & -74773.3 & -160370 & 124645.79 & -39049.37 \\
2003 & -209152 & -207154 & 121456.50 & -123454.56 \\
2004 & -225347 & -407967 & 241298.03 & -58677.91 \\
2005 & -215376 & -451541 & 289652.44 & -53487.83 \\
2006 & -291579 & -564039 & 349906.78 & -77446.74
\end{tabular}




$\begin{array}{lcccc}2007 & -281757 & -700006 & 462070.07 & -43821.15 \\ 2008 & -247552 & -843085 & 609648.28 & -14114.66 \\ 2009 & -433330 & -2139501 & 981280.06 & 724891.30 \\ 2010 & -443469 & -3480305 & 1344857.73 & 1691978.10 \\ 2011 & -391169 & -1781088 & 747044.62 & 642874.64 \\ 2012 & -486609 & -1533425 & 488045.93 & 558770.38 \\ 2013 & -176592 & -161488 & 147573.41 & -162676.79\end{array}$

The values of Producers \& Consumer Surplus are collecting from this study:

Norsida M. Sarmad A. H. and others (2016) Economic Analysis of the Multiple Effects of Single Market to Pricing Policy for Meat in Iraq. IOSR Journal of Business and Management (IOSR-JBM). Volume 18, Issue 10. PP 86-94

www.iosrjournals.org

For analyzing the results for fish to be seen supporting the output rate results was also negative with respect to the consumer most of the years of study. Because it was a single consumer unit output of beef is higher than the price of the gross domestic product price. That means that the state has achieved returns as a result of the price of the policy pursued by, as the recommended retail price was greater than the purchase price of the product. As it is shown in Table 3.

The amount of profits gained by the state characterized by fluctuating during the study period was the highest return $(69,935.4)$ thousand dinars in 2012 amounted to less than the return of the state through policy support (211.014) thousand dinars in 1990, when the negligence of reference for negative amount of the amount of money becomes returns to the State, rather than for the cost of support. Therefore we conclude that the price policy pursued by the state in support of product price Fish has achieved revenues for the state during the period of the study, as there was positive support for the price of the producers, while state support was negative and is a catalyst for the consumer. With the exception of the year (1985) all suffered there positive support for consumers fish, but the value was relatively low amounts comparator with revenues in the remaining years.

Table 3. State Support Amounts for Fish for the period (1985-2013)

\begin{tabular}{cccccc}
\hline Years & $\begin{array}{c}\text { Purchasing price } \\
(\mathrm{ID} \backslash \mathrm{Kg})\end{array}$ & $\begin{array}{c}\text { Consumer } \\
\text { price }(\mathrm{ID} \backslash \mathrm{Kg})\end{array}$ & $\begin{array}{c}\text { Support } \\
(\mathrm{ID} \backslash \mathrm{Kg})^{*}\end{array}$ & $\begin{array}{c}\text { consumption } \\
(\text { 000tons })\end{array}$ & $\begin{array}{c}\text { The total Support } \\
(\text { O000ID)* }\end{array}$ \\
\hline 1985 & 3.01 & 2.8 & 0.21 & 48 & 10.08 \\
1990 & 3.4 & 5.3 & -1.9 & 111.06 & -211.014 \\
1995 & 928 & 1600 & -672 & 34.99 & -23513.3 \\
2000 & 1744.3 & 2200 & -455.7 & 34.44 & -15694.3 \\
2001 & 1962.1 & 2068 & -105.9 & 30.7 & -3251.13 \\
2002 & 2081.1 & 2108 & -26.9 & 45.63 & -1227.45 \\
2003 & 1929 & 2125 & -196 & 21.05 & -4125.8 \\
2004 & 1990.7 & 2250 & -259.3 & 18.4 & -4771.12 \\
2005 & 2000.3 & 2255 & -254.7 & 34.7 & -8838.09 \\
2006 & 1973.3 & 2500 & -526.7 & 56.8 & -29916.6 \\
2007 & 2811.9 & 3000 & -188.1 & 56.5 & -10627.7 \\
2008 & 3650.5 & 3860 & -209.5 & 66.09 & -13845.9 \\
2009 & 4179 & 4700 & -521 & 74.74 & -38939.5 \\
2010 & 5989 & 6560 & -571 & 101.73 & -58087.8 \\
2011 & 6585 & 6955 & -370 & 81.67 & -30217.9 \\
2012 & 7100 & 7640 & -540 & 129.51 & -69935.4 \\
2013 & 6813 & 7350 & -537 & 102.2 & -54881.4 \\
\hline
\end{tabular}

Source: data prices and quantities are taken from the Ministry of Planning and the Ministry of Agriculture statistics

*Negative point to earn revenue of the state, while the positive represents the cost support price

Consequent price policy of the State to support the price of fish is also the cost of supplier support is this cost calculation as in beef by introducing changes in the surpluses of the producer and consumer calculated from the total of the state cost as a result of supporting output mentioned rate policy, in other words, the cost supplier is a those cost of the subsidy program after subtracting the producers and consumers the benefits and the measured changes in surplus producer and consumer of the product Fish, also said the cost (the cost of the supplier) is not 
benefiting producers and consumers but are paid by the state are considered administrative costs for the application of the subsidy program.

Table 4, shows the cost of the supplier of the values of the state during the period of the study. When you note the values in the table, we find that the State has achieved returns through policy interventions to support only the price of fish in the past $(1990,2000,2002,2003,2005,2006,2011,2012,2013)$ due to cost him support negative values during those years. We find that the values of these returns have fluctuated between increases and decreases have reached a higher amount $(142,784.734)$ thousand dinars in 2012 and reached its lowest amount (449.703) thousand dinars in 1990. State revenues will fluctuate on factors such as the volume of consumption and the price of a single-dependent as it's up these two variables increase state revenues and decreases the signal decreases.

The rest of the years of study that is not previously listed have resulted in the state the cost of the resource as a result of price support for the product Fish policy where the maximum amount reached her $(179,755.704)$ thousand dinars in 2010, the lowest amount it has reached (20.848) thousand dinars in 1985. Why the fluctuation of the cost of the resource values to factors such as the amount of consumption fish as well as a surplus producer and consumer surplus as these variables affect the overall cost of support and then the cost of supplier arising from product price support program.

Table 4. The Cost of Support the Price of Fish for the period (1985-2013) (000ID)

\begin{tabular}{ccccc}
\hline Years & The total Support & CS* & PS* & the cost of Support \\
\hline 1985 & 10.08 & -34.8658 & 24.09781 & 20.848 \\
1990 & -211.014 & 334.8817 & -96.193 & -449.703 \\
1995 & -23513.3 & 76018.91 & -148658 & 49126.271 \\
2000 & -15694.3 & -3955.47 & 2443.059 & -14181.900 \\
2001 & -3251.13 & -18622 & 11695.69 & 3675.161 \\
2002 & -1227.45 & -5147.38 & 4850.034 & -930.103 \\
2003 & -4125.8 & -6401.89 & 5151.533 & -2875.440 \\
2004 & -4771.12 & -16461.5 & 10377.97 & 1312.369 \\
2005 & -8838.09 & -21377.5 & 15083.24 & -2543.791 \\
2006 & -29916.6 & -17641.7 & 12569.99 & -24844.869 \\
2007 & -10627.7 & -68345.4 & 43728.2 & 13989.516 \\
2008 & -13845.9 & -128519 & 56918.98 & 57753.996 \\
2009 & -38939.5 & -175416 & 71762.52 & 64714.253 \\
2010 & -58087.8 & -348924 & 111080.8 & 179755.704 \\
2011 & -30217.9 & 15522.56 & -8979.09 & -36761.377 \\
2012 & -69935.4 & 149732.5 & -82430.8 & -137237.132 \\
2013 & -54881.4 & 290328.5 & -202425 & -142784.734 \\
\hline
\end{tabular}

The values of Producers \& Consumer Surplus are collecting from this study: Norsida M. Sarmad A. H. and others (2016) Economic Analysis of the Multiple Effects of Single Market to Pricing Policy for Meat in Iraq. IOSR Journal of Business and Management (IOSR-JBM). Volume 18, Issue 10. PP 86-94. $\quad$ www.iosrjournals.org

The returns achieved by the state of the application of the subsidy program got as a result of the cost of the negative support which arose because of the price differences between the purchase of the product price (product price) and the price of a single consumer as it was the result of the purchase price is less than the selling price (the price of the state) to the consumer, meaning that the sales price It was not in favor of the consumer. Therefore we conclude that the state has achieved returns through its policy of supporting the beef and fish, as well as that this policy is not in favor of the consumer during the years in which the state has achieved revenues and profits from its intervention in the pricing of goods.

\subsection{Result for Support Input Price}

calculate the amount of the total cost of support for input and output prices for the duration of the study as in tables $5 \& 6$. The cost of the overall support for the input price has fluctuated are the other in their amounts during the period of the study and the reason for this as we mentioned earlier to the amount of subsidy per unit of output and the amount of production taking into consideration the inflation in prices during the period of the study was the maximum amount of the cost of the overall support that incurred the state treasury $(987,235.49)$ thousand 
dinars in the year 1995, due to the high cost per unit of input and output support in the preceding year. The lowest amount of the cost of the overall support for the input and output was (162.65) thousand dinars in 1985 due to lower cost of input support. We excluded from this years $(2005,2006,2008)$ was the only state where the policy is not in favor of the product where the state has achieved the revenues from the sale of production inputs for producers. The largest was $(213,212.77)$ thousand dinars in 2008 . The reason for the negative to the amount of support to product.

Also when the state is supporting the production of input prices, it entails a cost of support supplier and that arise as a result of the application of the subsidy program and the cost of which does not benefit producers, but the state pays the costs for the implementation of the support program. For the cost of supplier product offering changes in excess of the cost of the overall support for input prices and beef production per year and thus we get the cost of the supplier of the input support price policy of production for the study. This is illustrated in 5 also it is seen as it has resulted in the state the cost of a resource in most years has been the amount of this cost fluctuating between increases and decreases, and the reason for this volatility to the amount of the total cost of support and the volume of changes within the product surplus and referring. The highest amount for the cost of emerging supplier because of the input support beef production prices was $(984,613.04)$ thousand dinars in 1995 The lowest amount it has been in (46.10) thousand dinars in 1990. But in the period (2004-2012), the State has achieved the revenue from the input support the production of beef prices, and it was the largest amount of revenue generated $(1,146,599.34)$ thousand dinars in 2010 , while the lowest amount was her $(188771.23)$ in 2004. The reason for the achievement of state revenues in the past mentioned the cost negative to support the input and output prices, since the state was imported production inputs certain prices (global prices) and sells to producers at prices higher than the purchase price, depending upon the size of the returns on the amount of the cost of the negative support the surplus on the size of the product and its reference.

Table 5. The Cost of Input Support in addition to the Cost Resulting from Resources to Support Input prices for Beef period (1985-2013)

\begin{tabular}{lccccccc}
\hline Years & $\begin{array}{c}\text { purchase price } \\
\text { of inputs } \\
\text { (ID } \backslash \mathrm{Kg})\end{array}$ & $\begin{array}{c}\text { Sell price of } \\
\text { inputs } \\
(\mathrm{ID} \backslash \mathrm{Kg})\end{array}$ & $\begin{array}{c}\text { Subsidy } \\
\text { (ID } \backslash \mathrm{Kg})\end{array}$ & $\begin{array}{c}\text { Production } \\
(000 \text { ton })\end{array}$ & $\begin{array}{c}\text { Total } \\
\text { subsidies } \\
(\text { (000 ID) }\end{array}$ & $\begin{array}{c}\text { PS } \\
\text { (000 ID) }\end{array}$ & $\begin{array}{c}\text { cost of resources to } \\
\text { support (000 ID) }\end{array}$ \\
\hline 1985 & 3.06 & 1.26 & 1.81 & 90 & 162.65 & 58.12 & 104.53 \\
1990 & 5.82 & 2.86 & 2.95 & 87 & 256.87 & 210.78 & 46.10 \\
1995 & 16193.71 & 2688.43 & 13505.27 & 73.1 & 987235.49 & 2622.45 & 984613.04 \\
2000 & 4052.80 & 1710.73 & 2342.07 & 70 & 163944.64 & 41818.45 & 122126.18 \\
2001 & 3880.27 & 1779.43 & 2100.84 & 65.5 & 137605.04 & 73250.99 & 64354.06 \\
2002 & 4552.53 & 2010.74 & 2541.79 & 130.5 & 331704.08 & 124645.79 & 207058.29 \\
2003 & 3400.99 & 2242.04 & 1158.95 & 131.9 & 152864.88 & 121456.50 & 31408.38 \\
2004 & 3281.17 & 2883.24 & 397.93 & 132 & 52526.80 & 241298.03 & -188771.23 \\
2005 & 2963.33 & 3482.23 & -518.90 & 134.1 & -69584.43 & 289652.44 & -359236.87 \\
2006 & 2853.91 & 4214.21 & -1360.29 & 136.3 & -185408.00 & 349906.78 & -535314.79 \\
2007 & 3611.54 & 3221.85 & 389.69 & 138.6 & 54010.40 & 462070.07 & -408059.67 \\
2008 & 1559.74 & 2984.00 & -1424.27 & 149.7 & -213212.77 & 609648.28 & -822861.05 \\
2009 & 6526.01 & 2232.92 & 4293.09 & 152.3 & 653837.45 & 981280.06 & -327442.61 \\
2010 & 3540.41 & 2260.50 & 1279.91 & 154.9 & 198258.39 & 1344857.73 & -1146599.34 \\
2011 & 3257.20 & 2876.95 & 380.25 & 157.7 & 59965.18 & 747044.62 & -687079.44 \\
2012 & 4458.15 & 2591.33 & 1866.82 & 160.5 & 299623.96 & 488045.93 & -188421.97 \\
2013 & 4896.69 & 2615.20 & 2281.49 & 156.35 & 356710.64 & 147573.41 & 209137.22 \\
\hline
\end{tabular}

Source: Source: data prices and quantities are taken from the Ministry of Planning and the Ministry of Agriculture statistics

In the results for Fish, we find the values listed in Table 6, we find that the state input support fish production during the period of the study. The reason is that the sale of these input prices to producers was less than their purchase price. This means that the state through the pricing policy of supporting the input and output prices for fish were in favor of the product for most of the years of study as well as in the results of beef. The total cost of support for input and output has fluctuated other is in their amounts during the period of the study and the reason for this as we mentioned earlier to the amount of subsidy per unit of output and the amount of production taking into consideration the inflation in prices during the period of the study. The maximum amount of the total cost of 
support resulting from the state treasury $(141,406.40)$ thousand dinars in the year 1995, due to the high cost of support per unit of input and output in the preceding year. The lowest amount of the cost of the overall support for the input and output was (27.42) thousand dinars in 1985 due to lower cost of input support. We excluded from this years $(2005,2006,2008)$ was the only state where the policy is not in favor of the product where the state has achieved the revenues from the sale of production inputs for producers. While the largest of $(20,649.47)$ thousand dinars in 2006. The reason the amount of negative support unit also output.

Also when the state is supporting the production of input prices, it entails a cost of support supplier and that arise as a result of the application of the subsidy program and the cost of which does not benefit producers, but the state pays the costs for the implementation of the support program.

For the cost of supplier product offering changes in excess of the cost of the overall support to prices, production inputs and fish each year and so we get the cost of the supplier of the input support price policy of production for the study. This is illustrated in Table 6, also it is seen as it has resulted in the state the cost of a resource in most years has been the amount of this cost fluctuating between increases and decreases, and the reason for this volatility to the amount of the total cost of support and the volume of changes within the product surplus and referring. The highest amount for the cost of emerging supplier because of the support input output prices for fish was $(290,064.86)$ thousand dinars in 1995. The lowest amount it has been (3.33) thousand dinars in 1985. But in the past period (2004-2010) it has achieved a state where revenues as a result of input support the production of beef prices, and it was the largest amount of revenue generated $(85,774.36)$ thousand dinars in 2010, while the lowest amount was her $(3,498.14)$ in the year 2009. Why achieving state revenues in the past mentioned the cost negative to support input prices, output, since the state was imported production inputs certain prices (international prices) and sells to producers at prices higher than the purchase price, depending upon the size of the returns on the amount of the cost of support and negative on the size of the product surplus and referring.

It concluded that the state was the catalyst of the product through the pricing policy input support the production and prices of meat and most of the years of the study period, but for a few years. That state revenues realized from the sale of production inputs for the product, and the general trend of the amounts of subsidies was beef larger than the fish. The trade-off between supporting output price and input support policy after it reached a price policy interventions of the state results in the support price of meat and input support prices, showing that the country has achieved returns through its policy of price intervention in support of the resulting price for years all of the study with the exception of some years for fish. It indicates a state that has achieved returns at the expense of both the producer and the consumer.

Table 6. The Cost of Input Support in addition to Cost Resulting from of Resources to Support Input prices for fish period (1985-2013)

\begin{tabular}{cccccccc}
\hline Years & $\begin{array}{c}\text { purchase price of } \\
\text { inputs } \\
(\mathrm{ID} \backslash \mathrm{Kg})\end{array}$ & $\begin{array}{c}\text { Sell price of } \\
\text { inputs } \\
(\mathrm{ID} \backslash \mathrm{Kg})\end{array}$ & $\begin{array}{c}\text { Subsidy } \\
(\mathrm{ID} \backslash \mathrm{Kg})\end{array}$ & $\begin{array}{c}\text { Production } \\
(\text { (000 ton) }\end{array}$ & $\begin{array}{c}\text { Total } \\
\text { subsidies } \\
(000 \mathrm{ID})\end{array}$ & $\begin{array}{c}\text { PS } \\
\text { (000 ID) }\end{array}$ & $\begin{array}{c}\text { cost of } \\
\text { resources to } \\
\text { support(000 ID) }\end{array}$ \\
\hline 1985 & 0.96 & 0.39 & 0.57 & 48 & 27.42 & 24.10 & 3.33 \\
1990 & 1.82 & 0.89 & 0.93 & 31.5 & 29.28 & -96.19 & 125.48 \\
1995 & 5059.39 & 825.66 & 4233.72 & 33.4 & 141406.40 & -148658.46 & 290064.86 \\
2000 & 1313.31 & 533.83 & 779.48 & 28 & 21825.36 & 2443.06 & 19382.30 \\
2001 & 1258.78 & 559.06 & 699.71 & 26 & 18192.59 & 11695.69 & 6496.90 \\
2002 & 1465.02 & 629.58 & 835.44 & 45.5 & 38012.48 & 4850.03 & 33162.44 \\
2003 & 1112.50 & 700.10 & 412.40 & 21 & 8660.36 & 5151.53 & 3508.82 \\
2004 & 1075.93 & 897.64 & 178.29 & 18.4 & 3280.56 & 10377.97 & -7097.41 \\
2005 & 978.65 & 1082.73 & -104.08 & 34.7 & -3611.48 & 15083.24 & -18694.72 \\
2006 & 945.19 & 1308.74 & -363.55 & 56.8 & -20649.47 & 12569.99 & -33219.46 \\
2007 & 1176.93 & 1011.94 & 164.99 & 54.4 & 8975.51 & 43728.20 & -34752.69 \\
2008 & 549.32 & 941.39 & -392.08 & 47.9 & -18780.54 & 56918.98 & -75699.52 \\
2009 & 2001.89 & 713.89 & 1288.01 & 53 & 68264.38 & 71762.52 & -3498.14 \\
2010 & 1180.96 & 728.25 & 452.71 & 55.9 & 25306.43 & 111080.79 & -85774.36 \\
2011 & 1042.74 & 911.65 & 131.09 & 48.8 & 6397.16 & -8979.09 & 15376.25 \\
2012 & 1373.83 & 824.05 & 549.78 & 67.9 & 37329.96 & -82430.81 & 119760.77 \\
2013 & 1514.83 & 831.49 & 683.33 & 56.4 & 38540.00 & -202425.13 & 240965.13 \\
\hline
\end{tabular}




\section{Conclusion}

There are two types of support policy which either support the final product price or subsidy input as both the two policies need large amounts from the state budget, as we explained in the previous. About support for input and output prices, followed by the state's policy has resulted in the state treasury the total cost of to support input meat production for most of the years of schooling prices with the exception of years, the State has achieved the revenues from the sale of production inputs to the producers at prices higher than the import prices of these inputs. So it turns out that the state returns achieved by supporting the price of meat adopted in the study period, but at the same time have borne the burden of administrative cost represented by the policy (the cost of the supplier) required to support the price of meat program application. About support for input and output prices policy, the State has achieved returns in some years of the study period, and the consequent cost of supporting the total cost of a resource in the other years of the rest of the school years from the foregoing that support input prices policy production of meat is the preferred policy of the state because it requires less expensive of its budget. It is advised to re-planning price support policies in order to serve a benefit of producers and consumers.

\section{References}

Bayaty, N. M. (2007). An Economic Analysis to Compare Between Production Price Support and Input Prices Policies of Table Egg Product In Iraq. PhD thesis in Agricultural Economics. College of Agriculture, University of Baghdad, Iraq.

Harrigan, J., Loader, R., \& Thirtle, C. (1992). Agricultural Price Policy: Government and the Market. FAO, Rome. pp. 136. http://catalogue.nla.gov.au/Record/508931

Manhal, M. A. (2006). The dimensions of the proposed strategy for the future development of the agricultural sector in Iraq, Ministry of Agriculture, the General Company for Agricultural Supplies, Iraq.

Ministry of Agriculture (2003) General Company for Livestock Services, fish farms Department reports.

Ministry of Planning, the Central Bureau of Statistics (NBS), the Department of Agricultural statistics, the annual reports of animal products. www.cosit.gov.iq

Ministry of Planning, the Central Bureau of Statistics (NBS), the Department of National Accounts, commodity balances for the years (1985-2013). www.cosit.gov.iq

Ministry of Planning, the Central Bureau of Statistics (NBS). Department of foreign trade statistics, the annual bulletins. www.cosit.gov.iq

Modha, Abdullah. A., \& Kanaan N. A. (2000). An economic analysis of price support and input subsidy of some of the major grain crops in Iraq". Union of Arab Agricultural, Society of Arab economic, agricultural and social sciences, the second scientific conference 11-15 $\backslash 4$ Baghdad, Iraq.

Norsida, M., Sarmad, A. H., \& others (2016). Economic Analysis of the Multiple Effects of Single Market to Pricing Policy for Meat in Iraq. IOSR Journal of Business and Management (IOSR-JBM). Volume 18, Issue 10. PP 86-94. www.iosrjournals.org

Zobaie, A. A. (1995). An economic analysis of the implications of supporting the prices of major cereal crops in Iraq for the period (1970-1990). Wheat specimen applied - doctoral thesis - Agricultural Economics, University of Baghdad, College of Agriculture, Iraq.

\section{Copyrights}

Copyright for this article is retained by the author(s), with first publication rights granted to the journal.

This is an open-access article distributed under the terms and conditions of the Creative Commons Attribution license (http://creativecommons.org/licenses/by/4.0/). 